\title{
11 \\ Budgeting and financial management of public infrastructure: The experience of Taiwan
}

\section{Yu-Ying Kuo and Ming Huei Cheng}

Public-private partnerships (PPPs) for public infrastructure have been the dominant model to create new job opportunities, expand domestic demand, stimulate the economy and deliver on infrastructure needs more efficiently in Taiwan. The Ministry of Finance $(\mathrm{MoF})$ has endeavoured to promote private participation in infrastructure projects, improve the quality of public services, accelerate social and economic development and control government financial expenditure.

Private investors can participate through build-operate-transfer (BOT), build-operate-own (BOO), rehabilitate-operate-transfer (ROT) and operate-transfer (OT) in accordance with the Promotion of Private Participation in Infrastructure Projects Act 2000 (PPIP Act). The Urban Renewal Act 2010 provides joint development and creates special rights to make use of government-owned land, while tax incentives provide some exemptions from business tax and customs duties. In terms of Taiwan's experience with PPPs, the key factors in public infrastructure funding are the financial feasibility of meeting the interests of all parties involved in PPP projects and ensuring public infrastructure investment plans focus on long-term effects. 


\section{Introduction}

In line with New Public Management (NPM) and governance, privatisation, contracting out and outsourcing are among the strategies that have been used in many countries to make greater use of private sector capacities in public sector management. In the face of fiscal difficulties and economic stagnation, several countries have also attempted to finance government infrastructure projects by incorporating private investment. This is to create new job opportunities, expand domestic demand and stimulate the economy, as well as to deliver on infrastructure needs more efficiently. This chapter analyses the budgeting and financial management of public infrastructure in Taiwan in terms of the government's objectives for promoting private participation.

PPPs for public infrastructure have been the dominant model in Taiwan. Key issues involved in promoting this model in Taiwan, as elsewhere, include the criteria for success (what the government is seeking), the allocation of risk and the criteria for selecting qualified private partners.

Such investment typically includes infrastructure such as energy (power generation and supply), transport (roads, rail systems, bridges and tunnels), water (sewerage, wastewater treatment and water supply), telecommunications (telephone and internet connections) and social infrastructure (hospitals, prisons, courts, museums, schools and government accommodation) (Grimsey and Lewis 2002: 108). PPPs are prevalent internationally-for instance, the United Kingdom issued its renewed 'PF2' (private finance) policy in late 2012 (HM Treasury 2012), while the Organisation for Economic Co-operation and Development (OECD 2012) has issued guidelines on how governments should proceed with PPPs. Likewise, member countries of the Association of Southeast Asian Nations (ASEAN 2014), with assistance from the OECD, have developed a new framework for PPPs. The European Commission (EC 2014) has launched an ambitious Investment Plan for Europe, which entails encouraging private financing of public infrastructure programs on a grand scale. US President Donald Trump's plan to spend US $\$ 550$ billion (A $\$ 695$ billion) over the next decade to upgrade the nation's crumbling roads, bridges and waterways has been celebrated as a key driver of the stock market's post-election rally and a potential jolt to a listless economy (Davidson 2016). According to Trump's economic adviser, the President's 
plan would depend heavily on private investors, which the federal government will encourage by providing very generous federal tax credits (Pianin 2016).

PPPs - in which the government contracts a private partner to variously finance, design, build and operate infrastructure assets for a fixed periodare growing in use. Government cooperation with the private sector via PPPs, which allows for the joint completion of public infrastructure and provision of services, has become a significant method to facilitate investment in public infrastructure as well as to stimulate the economy. This growth is due in large part to the scope of benefits PPPs offer to bring in terms of private sector management skills, the opportunities that bundling design, construction and operation provide to improve efficiency and the ability to bring forward the provision of infrastructure services. There can also be less scrutiny from off-budget financing.

While some governments focus on a particular type of long-term PPP contract — 'design, build, finance, operate and maintain' (DBFOM) — the reality is there are many possible contractual arrangements. Contracts may differ in terms of which of the different tasks and activities the public or private sector is held responsible for (from initial planning through to the final maintenance and operations), the extent of finance from each sector, the specific nature of the project to be delivered, which party bears which risks, the strength of incentives for performance as well as issues of transparency (Hodge and Greve 2013).

A PPP is a way of funding and delivering public infrastructure projects where project risks are shared between the public and the private sectors. Chan et al. (2009) argued that PPPs may assist in transferring construction and operational risks to private partners, while governments retain regulatory and demand risks with a commitment to underwrite minimum revenue from user charges. Therefore, the effectiveness of the alignment depends on a sufficient and appropriate transfer of risk to the private partner. But the complexities and risk transfers associated with the financing arrangements have also led to failures of the PPP model, particularly if the private investment involves indirect government borrowing (exacerbating problems with budget bottom lines). 
In the international literature, PPPs remain both widely praised and loudly criticised. For instance, Ross and Yan (2015) compare PPPs with traditional public procurement using economic theory. They acknowledge that one of the longstanding potential problems with PPPs is:

the loss of flexibility that comes with the long lived contractual obligations governments must respect when changing circumstances may require significant change in the way the public service is provided. (Ross and Yan 2015: 443)

Ross and Yan argue that PPPs will be superior to government provision (in terms of value for money or social surplus) when their potential efficiencies are large, the probability that there will need to be changes to the project is small, the gains to project redesign are small and when the government's bargaining power in renegotiation is greater. They suggest that PPPs ought to be more attractive for road or bridge projects, where there is little chance that a redesign will be needed, and less attractive for more dynamic projects such as healthcare or information technology projects.

Some scholars suggest PPPs offer more speedy investment in the economy, but warn against the dangers of poor regulation that leave excessive risks with government. Reeves (2015) draws attention to the fundamental shift in the Irish Government's motives for PPPs following the Global Financial Crisis (GFC) towards levering private funds for investment and job creation. He describes the origins of the policy prior to the GFC and points to the government's desire to alleviate capacity constraints on infrastructure delivery, to effect 'speedy delivery' of infrastructure and to achieve value for money. He concludes that PPPs did make a contribution to infrastructure investments over and above those that would have occurred anyway.

Albalate et al. (2015) compare the transfer of different types of risk in transport-related PPPs in many South American and European countries and highlight the importance of risk-mitigation strategies and of institutional quality and stability. For instance, they report that Spain suffered because of instability in PPP regulation, which led to the government bearing most of the financial risks. More recently, in a stable regulatory environment, the French Government was able to successfully allocate risks to its private partners. Financing challenges along with weak legal protections have inhibited private participation in PPPs. Albalate et al. concluded: 
countries with higher institutional quality and stability are able to engage in PPPs with fewer guarantees or less need for sharing the risks associated with demand, cost overrun and maintenance and operation. (2015: 496)

Care in risk allocation is emphasised, particularly for social-investment PPPs. Acerete et al. (2015) examine healthcare PPPs in Spain, which pioneered the 'Alzira model' to provide clinical services, with potentially attractive revenue streams, as well as physical infrastructure. They conclude that 'care is needed to avoid unwarranted inferences about claimed benefits of lower costs while maintaining sustainable quality' (Acerete et al. 2015: 503). Hellowell (2015) compared the agency problems that led to budgetary problems with PPP hospitals in the United Kingdom and Spain. He noted that, while PPPs have long been advocated on the grounds of efficiency, 'strategic misrepresentation' often occurs with public projects, with costs being deliberately underestimated and benefits deliberately overestimated to ensure favoured projects gain approval for funding (Hellowell 2015: 45).

Eldrup and Schütze (2013) point out that the apparent advantage of PPPs' access to private funding comes at a cost, as the PPP model leads to higher costs of finance compared with public funding and potentially costly changes subsequent to contract signature. In addition, the private partner may be tasked with the design, construction, financing, operation and management of the infrastructure asset and the delivery of a service to the government or to the public using that asset but most of the risk remains with the government. In many cases, failures of PPP projects are attributed to poor project preparation or financial shortages, where the advantages of private sector expertise and competitive processes do not outweigh the risks to government, including the cost of private sector financing. For PPPs with high involvement of state-owned enterprises, contingent liabilities may increase as a result of implicit or explicit government guarantees. Hansakul and Levinger (2016) argued that PPPs could add to explicit debt and could lead to higher financing costs. As a result, large-scale PPP programs risk being halted or terminated due to a change in political leadership or adverse economic circumstances. 


\section{Taiwan's experience}

Whether a government should invest in infrastructure projects to stimulate the economy or reduce investment to save government expenditure has long been debated in Taiwan. To some degree, private participation in public infrastructure projects can open up new opportunities for infrastructure investment ventures. The MoF is in charge of the PPIP Act. The PPIP Act is one of the MoF's most important policies, aimed at improving the quality of public services, accelerating social and economic development and containing government financial expenditure.

In addition to private sector participation in infrastructure projects through BOT, BOO, ROT and OT, in accordance with the PPIP Act, investors can also participate through the Urban Renewal Act 2010, via joint development and creation of special rights to make use of government-owned land. By building on the different strengths of the public and private sectors, partnerships between the two can result in appropriate allocation and sharing of risks in each project's design, implementation, logistics, legal changes and ongoing operational management, and can contribute to the success of a project by making use of the private sector's capital, operational efficiency and professional talent and by using competition to get maximum value for money. By attracting private participation, the MoF hopes to revitalise Taiwan's economy and better the lives of its people. With the long-term, steady revenue brought by PPP projects and the tax and land acquisition incentives provided by the PPIP Act, private investors can enjoy better profit margins, business expansion opportunities and enhance their corporate image. The MoF invites private investors to participate in quality PPP projects to create triple-win situations: higher revenues for investors, lower expenditure for government and better public services (MoF 2013).

Incentives under the PPIP Act are set out in Table 11.1. First, 'regulatory relaxation' refers to the elimination or relaxation of restrictions on government-owned land, such as leases longer than 10 years, and allowing the private sector to gain benefits from the land and from the issuance of corporate bonds by private institutions. Second, 'fundraising' means the authority in charge may subsidise part of the interest accrued from the loan needed by the private institution, invest in part of the construction or coordinate with financial institutions or special funds to provide mediumor long-term financing to the private institution. Third, 'preferential 
land rentals' are situations where the land required for the infrastructure project is government-owned but is rented in connection with a lease and superficies may be extended on favourable terms. For major infrastructure projects, the authority in charge may expropriate the land and provide it for use to a private institution. Moreover, tax incentives can include exemption from business income tax for five years, investment tax credits for capital expenditure, preferential customer duties on imported machinery and equipment, reduction of or exemption from building tax, land value tax and deeds tax and investment tax credits for subscriptions of shares issued by the private institution. For major transportation projects, relaxation of restrictions on lines of credit for loans is provided to private institutions.

Table 11.1 Incentives for promotion of private participation in public infrastructure projects

\begin{tabular}{|l|l|}
\hline Regulatory relaxation & $\begin{array}{l}\text { Elimination of restrictions under Article 25 of the Land Act: } \\
\text { Relaxes restrictions on disposition of government-owned land, } \\
\text { creation of encumbrances or leases longer than 10 years. } \\
\text { Elimination of restrictions under Article 28 of the National } \\
\text { Property Act and Local Government Property Management } \\
\text { Act: Relaxation of restrictions on the disposition of government- } \\
\text { owned property or the collection of benefits from it. } \\
\text { Elimination of restrictions under Article 270, Subparagraph 1, } \\
\text { of the Company Act: Relaxes restrictions on the issuance of } \\
\text { new shares by private institutions. } \\
\text { Elimination of restrictions under Article 247, Article 249, } \\
\text { Subparagraph 2, and Article 250, Subparagraph 2, of } \\
\text { the Company Act: Relaxes restrictions on the issuance } \\
\text { of corporate bonds by private institutions. }\end{array}$ \\
\hline Fundraising & $\begin{array}{l}\text { The authority in charge may, in the case of incapacity to cover } \\
\text { the portion of costs for self-financing, subsidise part of the } \\
\text { interest accrued from the loan needed by the private institution } \\
\text { or to invest in part of the construction. } \\
\text { The authority in charge may coordinate with financial } \\
\text { institutions or special funds to provide medium- or long-term } \\
\text { financing to the private institution. }\end{array}$ \\
\hline $\begin{array}{l}\text { Preferential land } \\
\text { rentals }\end{array}$ & $\begin{array}{l}\text { Where the land required for the infrastructure project is } \\
\text { government-owned, rentals in connection with the lease and the } \\
\text { creation of superficies may be extended on favourable terms. }\end{array}$ \\
\hline Major infrastructure projects ${ }^{1}$ \\
\hline $\begin{array}{l}\text { Expropriation of } \\
\text { privately owned land }\end{array}$ & $\begin{array}{l}\text { The authority in charge may expropriate the land and provide } \\
\text { it for use by the private institution. }\end{array}$ \\
\hline
\end{tabular}


VALUE FOR MONEY

\begin{tabular}{|l|l|}
\hline Tax incentives & Exemption from business income tax for five years. \\
& Investment tax credit for capital expenditure. \\
& $\begin{array}{l}\text { Preferential customer duties on imported machinery } \\
\text { and equipment. } \\
\text { Reduction of or exemption from building tax, land value tax } \\
\text { and deeds tax. } \\
\text { Investment tax credits for subscriptions of shares issued } \\
\text { by the private institution. }\end{array}$ \\
\hline Loan credits & $\begin{array}{l}\text { Relaxation of restrictions on lines of credit for loans provided } \\
\text { to private institutions (only for major transportation projects). }\end{array}$ \\
\hline
\end{tabular}

${ }^{1}$ Major infrastructure projects are those that are important and of a certain scale, the scope of which will be determined by the competent authority in conjunction with other relevant authorities.

Source: MoF (2013).

The Statute for Encouragement of Private Participation in Transportation Infrastructure Projects also provides tax incentives, including exemptions from business tax and customs duties (for details, see Appendix 11.1). The tax incentives create tax expenditure ranging from NT $\$ 195.2$ million (A \$8.2 million) to NT\$997.05 million (A $\$ 42$ million), but evaluations by the MoF and the Ministry of Transportation and Communications claim the benefits of PPPs outweigh the costs from tax expenditure.

Each project is subject to a strict approval process. Based on Article 34 of the Budget Act — covering major public construction projects and major policy implementation plans-before the budget estimates and budget proposals are compiled, a cost-efficiency analysis report that canvasses alternative measures must be drawn up, with a full description of the financing arrangements proposed. This report must be forwarded to the Legislative Yuan (DGBAS 2015). As shown in Figure 11.1, for each PPP project, the government conducts a social cost-benefit analysis (CBA) on the legal, market, environmental and financial aspects, including opportunity costs and indirect costs/benefits. Only project proposals deemed feasible will be publicly released for private investment. 
11. BUDGETING AND FINANCIAL MANAGEMENT OF PUBLIC INFRASTRUCTURE

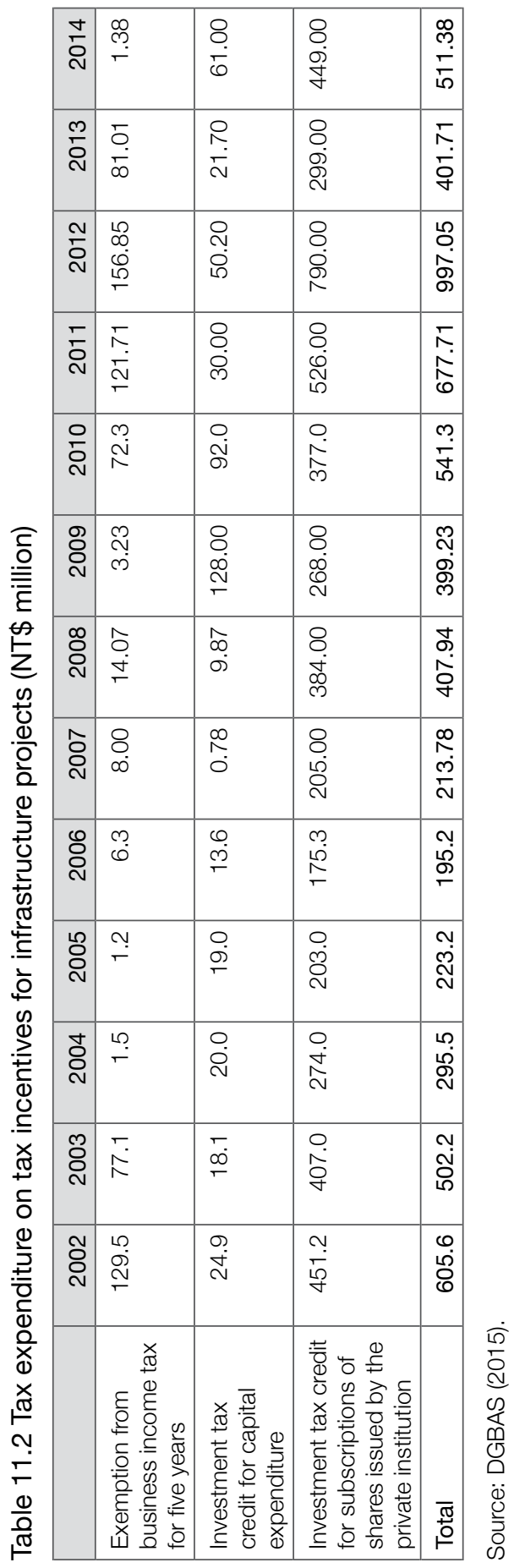




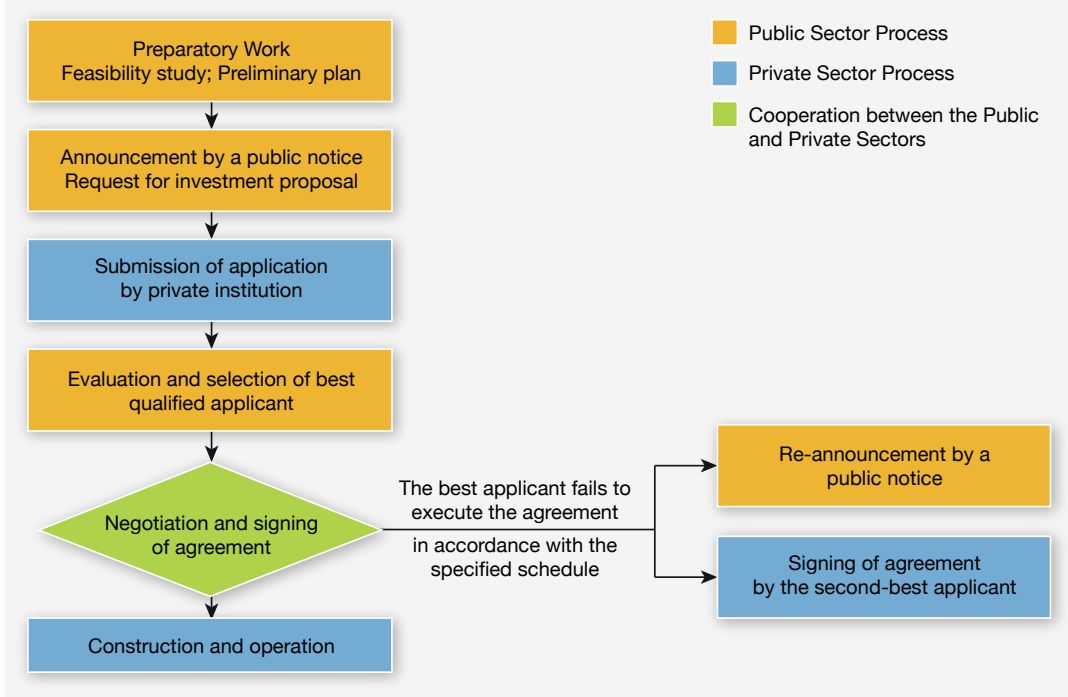

Figure 11.1 Application and evaluation procedure for government planned projects

Source: MoF (2013).

Furthermore, each private sector applicant must include their financial institution's evaluation opinion on the investment proposal when submitting a letter of intent. The principal condition for providing private financing may be stated in the evaluation opinion. Before inviting private participation through a public notice, the authority in charge may, depending on the character of the infrastructure project, provide general information to private investors about the project or conduct an information meeting, finalising the contents of public notices and tender documents after consulting with private investors. The public notice includes the following content:

1. the character, basic requirements, concession period and scope of the infrastructure project

2. qualification requirements for the applicant

3. items and standards of application review

4. items awaiting negotiation

5. the date of announcement, deadline for application, the application procedure and the deposit required

6. the scope for ancillary enterprises allowed for private investment and the concession period for the land needed

7. the matters authorised or commissioned by the authority in charge. 
The tender documents need to cover the following items:

1. the main content and format of the investment proposal

2. the measure and schedule of application review

3. commitment and cooperation matters required of the government

4. items and procedures for negotiation once negotiations are allowed

5. the deadline for contract negotiation and execution

6. a draft of the proposed concession agreement.

Where an infrastructure project in which a private institution participates is for a public utility enterprise, according to Article 49, the private institution may set the user charge and schedule and method for the adjustment of user charges in the financial plan submitted in its application. The financial plan is to include: 1) the cost expenditure for planning, construction, operation and other financial matters; 2) the income derived from operations and ancillary enterprises; 3 ) the operation period; 4) payment of any royalties; and 5) the price index used.

The user charge and the schedule and method for the adjustment of the user charge must be approved by the relevant authority in charge of the public utilities concerned before the execution of the concession agreement by the authority and the private institution in accordance with applicable laws. If, after the operation of the infrastructure project, it is necessary to make any adjustment to the user charge and/or the schedule and method for the adjustment of the approved user charge, this must first be approved by the competent authority in charge of the public utilities in accordance with applicable laws. The competitive assessment of user charges is part of the CBA to ensure reasonable costs to consumers. Afterwards, the authority in charge shall have the concession agreement modified accordingly and announced via a public notice.

The Statute for Encouragement of Private Participation in Transportation Infrastructure Projects has similar provisions. For public infrastructure in Taiwan, the central government adheres to the policy implementation principle of 'putting Taiwan first for the benefit of the people', proposed by former president Ma Ying-jeou in 2008. To map out a vision for national development, and set clear macroeconomic targets, Taiwan has introduced a plan built on six 'main axial policies': undertaking spatial remodelling, promoting industrial renovation, pursuing global linkages, cultivating innovative manpower, establishing a just society and achieving 
a sustainable environment. The ultimate goal is to develop Taiwan into an advanced country marked by vitality, innovation, equitable spread of wealth, social justice, sustainability and energy conservation.

Under the title 'i-Taiwan', 12 projects constitute an important economic development blueprint for Taiwan, designed to boost dynamism in the country's economic growth, which, in recent years, has been losing momentum against the headwinds of globalisation and intensifying international competition. The purpose of the projects is to expand domestic demand, improve the investment environment and boost the health of the economy and quality of life. The i-Taiwan 12 projects cover four dimensions: transportation networks, industrial innovation, urban and rural development and environmental protection. The 12 projects are detailed in Appendix 11.2 and summarised in Table 11.3.

Table 11.3 i-Taiwan 12 projects

\begin{tabular}{|c|c|}
\hline Transportation Network & Industrial Innovation \\
\hline $\begin{array}{l}\text { - A fast and convenient transportation } \\
\text { - } \text { Ketwork } \\
\text { - Taohsiung Port-City regeneration } \\
\text { - Taoyuan International Airport City }\end{array}$ & $\begin{array}{l}\text { - } \quad \text { Central Region New High-Tech } \\
\text { Industrial Clusters Program } \\
\text { - } \quad \text { Intelligent Taiwan } \\
\text { - } \quad \text { Industrial innovation corridors }\end{array}$ \\
\hline Urban and Rural Development & Environmental Protection \\
\hline $\begin{array}{l}\text { - Urban and industrial park regeneration } \\
\text { - Farm village regeneration }\end{array}$ & $\begin{array}{l}\text { - } \quad \text { Coastal regeneration } \\
\text { - } \quad \text { Green forestation } \\
\text { - } \text { management } \\
\text { - Sewer construction }\end{array}$ \\
\hline
\end{tabular}

Source: Invest Taiwan (2015).

With regard to transportation, the i-Taiwan projects constitute the main means for integrating Taiwan's high-speed rail, Taiwan Railways and the metropolitan Taipei Mass Rapid Transit (MRT) networks, and improving the integration of freeways and other roads to build a fast and convenient island-wide transportation network. They will also enhance Kaohsiung Port's geographic advantage as a shipping hub, speed up the regeneration of the port and Kaohsiung City and improve airport links, speed up airport operations and peripheral construction and develop Taoyuan International Air City.

The second-largest dimension of the projects-industrial innovationincludes major investments in education, a nationwide wireless broadband system, intelligent transport systems as well as new industrial clusters, corridors and parks. Construction mechanisms for effectively attracting 
private investment include quality-control mechanisms for the life cycle of public works, strengthening the competitiveness of the engineering industry and comprehensively raising the quality of public construction and services.

The Taiwanese Government has been eager to strengthen investment in public construction and has endeavoured to encourage private participation in public construction projects. These projects are expected to deliver economic benefits by bolstering public infrastructure, revitalising the domestic economy, promoting investment, increasing income and employment opportunities, upgrading the quality of life and improving the equitable distribution of income. The Taiwanese Government will carry out its 'Strategic Plan for the Spatial Development of National Land' to achieve a new vision for the country's spatial development through such strategies as hazard prevention and land restoration, sustainable urban and rural development and green and intelligent transportation. Overall, the government believes that the 12 prioritised public construction projects can regenerate Taiwan's economy.

Table 11.4 indicates total investment in i-Taiwan projects will be almost NT\$4 trillion (A $\$ 169$ billion), with private investment comprising about 30 per cent, or NT\$1.3 trillion (A $\$ 53.6$ billion). Among the 12 projects, the fast, convenient transportation network is the biggest investment project, involving NT $\$ 1.2$ trillion (A $\$ 51.3$ billion), or more than 30 per cent of the total investment. The second-largest investment is 'Intelligent Taiwan' and the third-largest is 'Urban and Industrial Park Regeneration'. It is estimated about 120,000 direct employment opportunities were created each year over the period of the project (2008-16).

Table 11.4 Total investment and private investment in i-Taiwan 12 projects

\begin{tabular}{|l|r|r|r|}
\hline Item & \multicolumn{1}{|c|}{$\begin{array}{c}\text { Total } \\
\text { investment } \\
\text { (NT\$ billion) }\end{array}$} & $\begin{array}{c}\text { Private } \\
\text { investment } \\
\text { (NT\$ billion) }\end{array}$ & $\begin{array}{c}\text { Private } \\
\text { investment (\%) }\end{array}$ \\
\hline $\begin{array}{l}\text { A fast convenient transportation } \\
\text { network }\end{array}$ & $1,215.70$ & 76.30 & 6.28 \\
\hline $\begin{array}{l}\text { Kaohsiung Port-City } \\
\text { reconstruction }\end{array}$ & 38.80 & 16.10 & 21.45 \\
\hline $\begin{array}{l}\text { Taoyuan International } \\
\text { Airport City }\end{array}$ & 293.70 & 64.4 & 69.66 \\
\hline Transportation Network & $1,548.20$ & 156.80 & 67.21 \\
\hline $\begin{array}{l}\text { Central Region New High-Tech } \\
\text { Industrial Cluster Program }\end{array}$ & 323.00 & 217.1 & \\
\hline
\end{tabular}


VALUE FOR MONEY

\begin{tabular}{|l|r|r|r|}
\hline Item & \multicolumn{1}{|c|}{$\begin{array}{c}\text { Total } \\
\text { investment } \\
\text { (NT\$ billion) }\end{array}$} & $\begin{array}{c}\text { Private } \\
\text { investment } \\
\text { (NT\$ billion) }\end{array}$ & $\begin{array}{c}\text { Private } \\
\text { investment (\%) }\end{array}$ \\
\hline Intelligent Taiwan & 775.20 & 357.60 & 46.13 \\
\hline Industrial innovation corridors & 147.50 & 76.10 & 51.60 \\
\hline Industrial Innovation & $1,245.70$ & 650.80 & 164.94 \\
\hline $\begin{array}{l}\text { Urban and industrial park } \\
\text { regeneration }\end{array}$ & 458.20 & 373.30 & 81.48 \\
\hline Farm village regeneration & 208.40 & 10.20 & 4.92 \\
\hline Urban and Rural Development & 666.60 & 383.50 & 86.40 \\
\hline Coastal regeneration & 39.40 & 1.80 & 4.45 \\
\hline Green forestation & 59.80 & 0.60 & 0.95 \\
\hline $\begin{array}{l}\text { Flood prevention and water } \\
\text { management }\end{array}$ & 273.00 & 0.00 & 0.00 \\
\hline Sewer construction & 162.90 & 77.10 & 4.73 \\
\hline Environmental Protection & 535.10 & 79.50 & 10.13 \\
\hline Total & $3,995.60$ & $1,270.60$ & 31.80 \\
\hline
\end{tabular}

Source: Invest Taiwan (2015).

Table 11.5 shows that, in terms of private investment, the top three projects are the Central Region New High-Tech Industrial Cluster Program, Intelligent Taiwan and the urban and industrial park regeneration (comprising nearly 80 per cent of the total private investment). The specific projects within these include Taichung Science Park, advanced research parks, central regional machine-driven industry development, Taichung Harbour logistics district, construction of wireless broadband, digital content and design industry, radio-frequency identification construction, urban regeneration, industrial park regeneration and highspeed rail station district development.

Table 11.5 Major private investment projects

\begin{tabular}{|l|c|l|}
\hline Item & $\begin{array}{c}\text { Private investment } \\
\text { (NT\$ million)/ } \\
\text { percentage of total } \\
\text { investment }\end{array}$ & $\begin{array}{l}\text { Major private investment } \\
\text { projects }\end{array}$ \\
\hline $\begin{array}{l}\text { A fast convenient transportation } \\
\text { network }\end{array}$ & $76.3 / 6.4 \%$ & $\begin{array}{l}\text { Constructions of MRT systems } \\
\text { in three metropolitan areas, } \\
\text { grade separation and rapid } \\
\text { transit systematisation of city } \\
\text { railways. }\end{array}$ \\
\hline $\begin{array}{l}\text { Kaohsiung Port-City } \\
\text { reconstruction }\end{array}$ & $16.1 / 1.3 \%$ & $\begin{array}{l}\text { Construction of international } \\
\text { container terminal. }\end{array}$ \\
\hline
\end{tabular}




\begin{tabular}{|c|c|c|}
\hline Item & $\begin{array}{l}\text { Private investment } \\
\text { (NT\$ million)/ } \\
\text { percentage of total } \\
\text { investment }\end{array}$ & $\begin{array}{l}\text { Major private investment } \\
\text { projects }\end{array}$ \\
\hline $\begin{array}{l}\text { Taoyuan International } \\
\text { Airport City }\end{array}$ & $64.4 / 5.4 \%$ & $\begin{array}{l}\text { Airport city development, } \\
\text { construction of Terminal } 3\end{array}$ \\
\hline Transportation Network & $156.8 / 13 \%$ & \\
\hline $\begin{array}{l}\text { Central Region New High-Tech } \\
\text { Industrial Cluster Program }\end{array}$ & $217.1 / 18.1 \%$ & $\begin{array}{l}\text { Taichung Science Park, } \\
\text { advanced research park, } \\
\text { central region machine-driven } \\
\text { industry development, Taichung } \\
\text { Harbour logistics district }\end{array}$ \\
\hline Intelligent Taiwan & $357.6 / 29.8 \%$ & $\begin{array}{l}\text { Construction of wireless } \\
\text { broadband, digital content } \\
\text { and design industry, radio- } \\
\text { frequency identification } \\
\text { construction }\end{array}$ \\
\hline Industrial Innovation Corridors & $76.1 / 6.3 \%$ & $\begin{array}{l}\text { Science/technology parks, } \\
\text { Hsinchu Biomedical, Agriculture } \\
\text { Technology Park, Kaohsiung } \\
\text { Software Technology Park }\end{array}$ \\
\hline Industrial Innovation & $650.8 / 54.2 \%$ & \\
\hline $\begin{array}{l}\text { Urban and industrial park } \\
\text { regeneration }\end{array}$ & $373.3 / 31.1 \%$ & $\begin{array}{l}\text { Urban regeneration of } 30 \\
\text { locations, industrial park } \\
\text { regeneration, high-speed rail } \\
\text { station district development }\end{array}$ \\
\hline Farm village regeneration & $10.2 / 0.9 \%$ & $\begin{array}{l}\text { Farm Village Regeneration Plan, } \\
\text { 'Small landowner, big farmer' }\end{array}$ \\
\hline Urban and Rural Development & $383.5 / 32 \%$ & \\
\hline Coastal regeneration & $1.8 / 0.1 \%$ & $\begin{array}{l}\text { Diversified economic } \\
\text { development of fishing ports } \\
\text { and villages }\end{array}$ \\
\hline Green forestation & $0.6 / 0.1 \%$ & Lowland forest recreation areas \\
\hline $\begin{array}{l}\text { Flood prevention and water } \\
\text { management }\end{array}$ & $0 / 0 \%$ & \\
\hline Sewer construction & $77.1 / 0.6 \%$ & Sewer construction \\
\hline Environmental Protection & $79.5 / 0.8 \%$ & \\
\hline Total & $1,270.6 / 100 \%$ & \\
\hline
\end{tabular}

Source: Invest Taiwan (2015).

The Taiwanese Government is giving priority to public infrastructure and expects it to raise the economic growth rate. While most i-Taiwan projects are ongoing, after President Tsai Ing-wen took office in 2017, they no longer appeared in the budget. To take fiscal year 2017, for example, the public infrastructure budget amounted to NT $\$ 186.9$ billion 
(A $\$ 7.9$ billion), shown in Table 11.6, which accounted for 9.4 per cent of total government expenditure (NT $\$ 2$ trillion [A $\$ 84.3$ billion]). If coupled with special budget, enterprise and non-enterprise funds, the annual amount of public infrastructure projects in 2017 will add up to NT $\$ 326.6$ billion (A $\$ 13.8$ billion). This budget funding excludes private investment and tax expenditures. Parts of the projects under the headings Transportation Network, Urban and Rural Development and Environmental Protection are included in the 2017 budget, but the projects have been reassembled so it is hard to determine what is going on.

Table 11.6 Public infrastructure projects, 2017 (NT\$ billion)

\begin{tabular}{|c|c|c|c|c|c|c|}
\hline Item & Budget & $\begin{array}{l}\text { Special } \\
\text { budget }\end{array}$ & $\begin{array}{l}\text { Enterprise } \\
\text { funds }\end{array}$ & $\begin{array}{c}\text { Non- } \\
\text { enterprise } \\
\text { funds }\end{array}$ & Total & Percentage \\
\hline Total & 186.9 & 15.7 & 93.1 & 30.9 & 326.6 & 100.0 \\
\hline 1. Transportation & 96.2 & - & 13.1 & 12.4 & 121.7 & 37.3 \\
\hline Road & 44.7 & - & - & 3.8 & 48.5 & 14.9 \\
\hline Railway & 44.8 & - & 1.2 & 0.7 & 46.7 & 14.3 \\
\hline Air & - & - & 7.1 & 0.5 & 7.6 & 2.3 \\
\hline Harbour & 2.5 & - & 4.8 & 6.3 & 13.6 & 4.2 \\
\hline Tourism & 4.2 & - & - & 1.1 & 5.3 & 1.6 \\
\hline 2. Environment & 28.7 & 13.0 & 13.0 & 2.8 & 57.5 & 17.6 \\
\hline Protection & 2.8 & - & - & 0.7 & 3.5 & 1.1 \\
\hline Water & 12.2 & 11.0 & 13.0 & 2.1 & 38.3 & 11.7 \\
\hline Sewer & 12.0 & 2.0 & - & - & 14.0 & 4.3 \\
\hline National parks & 1.7 & - & - & - & 1.7 & 0.5 \\
\hline $\begin{array}{l}\text { 3. Economy and } \\
\text { energy }\end{array}$ & 4.6 & - & 67.0 & 3.3 & 74.9 & 22.9 \\
\hline Facility & 4.6 & - & 6.9 & 3.3 & 1.48 & 4.5 \\
\hline Electricity & - & - & 60.1 & - & 60.1 & 18.4 \\
\hline $\begin{array}{l}\text { 4. Urban } \\
\text { regeneration }\end{array}$ & 5.4 & - & - & 8.6 & 14.0 & 4.3 \\
\hline 5. Cultural facility & 8.7 & - & - & 0.3 & 9.0 & 2.8 \\
\hline 6. Education & 12.1 & - & - & 0.1 & 12.2 & 3.7 \\
\hline Education & 7.4 & - & - & 0.1 & 7.5 & 2.3 \\
\hline Sports & 4.7 & - & - & - & 47.0 & 1.4 \\
\hline 7. Agriculture & 30.2 & 2.7 & - & 0.9 & 338.0 & 10.4 \\
\hline 8. Health and welfare & 1.0 & - & - & 2.5 & 35.0 & 1.0 \\
\hline
\end{tabular}

- no data.

Source: Directorate-General of Budgeting, Accounting and Statistics (www.dgbas.gov.tw/ mp.asp?mp=1). 


\section{Some strengths and weaknesses of Taiwan's approach}

Under fiscal constraints, effective use of models encouraging private participation in public development projects, such as BOT, will help ease some of the financial pressure on government infrastructure programs. There are numerous laws governing private participation in infrastructure projects, including, since 2000, the PPIP Act and, since 1994, the Statute for Encouragement of Private Participation in Transportation Infrastructure Projects. The different objectives and operating guidelines of each law together make up a sound legal environment that has contributed to many successful cases over the past decades. To stimulate economic development, in 2012, the Executive Yuan passed the Economic PowerUp Plan. It designated using private investment to spur public works and expand investor solicitation. Whenever there is an infrastructure project, the feasibility of private participation will be assessed as a priority.

Since 2003, more than 1,000 contracts have been signed, totalling over NT $\$ 1$ trillion (A $\$ 42.2$ billion) in value. Over their lifetime, these agreements were estimated to save the government NT\$930 billion (A $\$ 39.2$ billion) in expenditure, add NT $\$ 670$ billion (A $\$ 28.3$ billion) in revenue and create more than 180,000 employment opportunitiesall while allowing the government to provide excellent public services. To continue promoting such achievements, the MoF gathered proposals from government agencies to offer an estimated NT $\$ 150$ billion (A $\$ 6.3$ billion) in investment opportunities to the private sector in 2015 (MoF 2015).

Notwithstanding the claimed benefits, infrastructure development in Taiwan in the past few years has experienced significant problems. First, an excessive number of infrastructure programs have distracted the public from the essence of the overall infrastructure strategy. Many infrastructure programs have been wrapped up in package deals, which appear to have become must-do tasks for each cabinet rather than changing in response to the ever-changing environment. In retrospect, many of the programs have not fulfilled their purpose. As it is often impossible to see the effect of infrastructure programs right away, people have, in general, felt the frustration of expecting too much and not being able to feel the actual benefits (Huang 2008). 
Second, there has been a lack of reasonable evaluation methods to assess the achievement of each program. Despite the MoF's requirement for social CBAs before projects are approved, evaluations are not always valid, resulting in poor investments that cause Taiwanese people to lose faith in the necessity of various infrastructure programs. Moreover, there is no systematic evaluation of completed projects to check whether the costs and benefits originally expected have been generated. The Council for Economic Planning and Development and the Public Construction Commission have attempted to develop a model suitable for application in Taiwan. Their efforts, however, have often been thwarted by political interference. Resources, as a result, are often assigned to the wrong places, leaving worthy sectors constantly in want of capital (Huang 2008).

The third weakness lies with the fact that the attention placed on the potential for financial leverage has long overwhelmed the attention given to financial efficiency. In recent years, Taiwan's finances have been in poor shape, and most local governments have run out of resources for capital investment. The job of scrutinising investment often falls to the media. Media reports can be biased and journalists may be unfamiliar with the legal requirements and professional assessments. Taken together, these three issues mean that development resources are likely to have been misplaced, with implications for the next stage of development in Taiwan (Huang 2008).

The new Taiwanese Government would do well to fund a more efficient procurement model that addresses these three weaknesses. As different countries are at different stages of development and face diverse macroeconomic backdrops and endowments, suitable financing options for infrastructure development will vary. Governments and multilateral agencies will remain important providers of funding, but the role of private financing looks set to grow. This underscores the need to put more effort into improving transparency and governance as well as enhancing cooperation in harmonising capital market standards and facilitating cross-border flows (Hansakul and Levinger 2016).

Although financing preferences will differ according to the macroeconomic and capital market conditions of each country, successful fundraising as well as project completion will depend on factors such as fiscal discipline and governance standards. Private investors, eager to benefit from longterm investment, can be enticed to take a greater role in infrastructure 
financing, but, as with public sector investment, this requires greater transparency, assessments of value for money and a more solid institutional framework-areas in which the government could improve its processes.

\section{Discussion and conclusion}

Private participation in infrastructure development is often promoted as it provides a popular option for public service delivery under fiscal constraint, offers opportunities for greater efficiency and innovation through competition and provides stable and long-term investment opportunities for the private sector. Governments have played the dominant role in owning and operating infrastructure facilities such as schools, hospitals, roads, bridges, railways, ports, telecommunications networks and water and electricity supply facilities. Their investment in infrastructure has been justified as a response to natural monopolies, and where the infrastructure services are seen as essential to the public good. Despite facing financial difficulty, governments are looking to expand investments in infrastructure projects as a source of fiscal stimulus, with the twin objectives of job creation and improving economic performance.

While these features may justify some public funding for infrastructure services, on their own they do not require public provision of infrastructure. Efficient financing is one element of efficient investment. The costs of financing large and complex infrastructure projects are substantial, so the savings from getting it right can be significant. The financing vehicle may provide information and create incentives that improve other aspects of an efficient investment decision. It may facilitate a better and narrower definition of any natural monopolies and thereby allow greater use of market competition to improve efficiency and promote innovation. Such vehicles should minimise the lifetime financing costs of a project. While the major financing task is meeting upfront investment costs in a timely manner, the central efficiency issue is which financing vehicle best manages project risk. Financing vehicles that assign risk to the partner best placed to manage each type of risk are more efficient, reducing the overall cost of the project. There may also be scope for the financing vehicle to influence allocative efficiency by imposing greater discipline on investment and funding decisions. 
Investment in infrastructure development is the cornerstone of regional competition for efficiency and sustainability. Due to the participation of emerging developing countries in this competition and ever-changing domestic production elements and trade conditions, Taiwan's overall economic environment, which originally relied on exports as its chief growth engine, is being challenged. Therefore, effective use of the local market to boost the national economy becomes a feasible policy option, while continuous development of infrastructure is an important component of local demand. More importantly, it takes qualitative and quantitative enhancement of infrastructure to facilitate investment and improve living environments. In the midst of global competition, this can attract foreign investment and can play an instrumental role in keeping local capital in Taiwan for domestic development. At the turning point of industrial transformation, Taiwan's next phase of development will be dependent on whether its infrastructure development projects are more attractive than those of its competitors, whether it is more appealing to domestic/foreign investors and attracts international intelligence to help Taiwan become a better location for industrial activities and in which to live.

In terms of Taiwan's experience with PPPs, the key factor in public infrastructure funding is the financial feasibility of meeting the interests of all parties involved in such projects. During the tendering stages, the issues of transparent bidding and concrete concession agreements are most evident when unanimity exists between the government and interest groups. Also, project financing, efficient structuring of PPPs and negotiation focused on achieving win-win outcomes are the important factors during the project development phase, while experienced construction contractors and appropriate cost and quality control are the most significant factors during the construction phase. The use of the PPP concept in a well-defined legal environment offers the advantages of stimulating investment and promoting private participation in infrastructure development. To achieve best results when applying this concept, the critical factors identified in this chapter need to be addressed before the project's model is adopted.

Lessons from Taiwan's experience can be summed up as follows: 1) a public infrastructure investment plan must focus on long-term effects; 2) the expansion of public investment helps to stimulate the economy in the short term; 3) the widespread use of (flexible) financing tailored to the specific needs of each project offers the opportunity for increased 
efficiency and returns on investment; and 4) cost-benefit calculations help in the decision of whether to engage in a PPP. The budgeting and financial management of private participation in Taiwan's infrastructure encourage efficient financing and efficient investment through a bottomup approach. Important lessons include the design of incentives to induce private investment and a careful review system to incorporate CBA. The enhancement of public-private infrastructure management, creation of win-win incentives, the promotion of a self-liquidating mechanism and the establishment of local government fiscal systems are essential for improving public-private partnerships.

\section{References}

Acerete, B., M. Gasca, A. Stafford and P. Stapleton. 2015. 'A comparative policy analysis of healthcare PPPs: Examining evidence from two Spanish regions from an international perspective'. Journal of Comparative Policy Analysis: Research and Practice 17(5): 502-18. doi.org/10.1080/13876988.2015.1010789.

Albalate, D., G. Bel, P. Bel-Piñana and R. R. Geddes. 2015. 'Risk mitigation and sharing in motorway PPPs: A comparative policy analysis of alternative approaches'. Journal of Comparative Policy Analysis: Research and Practice 17(5): 481-501. doi.org/10.1080/1387 6988.2015.1010788.

Association of Southeast Asian Nations (ASEAN). 2014. ASEAN Principles for PPP Frameworks. Jakarta: ASEAN Secretariat.

Boardman, A. E., C. Greve and G. A. Hodge. 2015. 'Comparative analyses of infrastructure public-private partnerships'. Journal of Comparative Policy Analysis: Research and Practice 17(5): 441-7. doi.org/10.1080/1 3876988.2015 .1052611$.

Chan, C., D. Forwood, H. Roper and C. Sayers. 2009. Public infrastructure financing: An international perspective. Staff Working Paper, 31 March. Melbourne: Productivity Commission.

Davidson, P. 2016. 'Trump's infrastructure plan: Potholes or a smooth ride?' USA Today, 16 November. Available from: www.usatoday. $\mathrm{com} /$ story/money/2016/11/16/trumps-infrastructure-plan-potholessmooth-ride/93890402/ (accessed 17 July 2017). 
Directorate-General of Budget, Accounting and Statistics (DGBAS). 2015. Global Reach: Achieving quality. Taipei City: DGBAS. Available from: www.dgbas.gov.tw/ (accessed 17 July 2017).

Eldrup, A. and P. Schütze. 2013. Organisation and financing of public infrastructure projects: A path to economic development of the Danish Welfare Model. Main report. Copenhagen: Offentligt-Privat Partnerskab.

European Commission (EC). 2014. An Investment Plan for Europe. Brussels: European Commission.

Grimsey, D. and M. K. Lewis. 2002. 'Evaluating the risks of public private partnerships for infrastructure projects'. International Journal of Project Management 20: 107-18. doi.org/10.1016/S0263-7863(00)00040-5.

Hansakul, S. and H. Levinger. 2016. 'Asia infrastructure financing: Getting it right would lift medium-term growth'. DB Research Management (January): 1-14.

Hellowell, M. 2015. 'Public investment as a driver of economic development and growth: What is the appropriate role of publicprivate partnerships?' In S. Caselli, V. Vecchi and G. Corbetta (eds) Public-Private Partnerships for Infrastructure and Business Development: Principles, practices, and perspectives. London: Palgrave Macmillan. doi.org/10.1057/9781137541482_3.

Her Majesty's (HM) Treasury. 2012. A New Approach to Public-Private Partnerships. London: HM Treasury.

Hodge, G. A. and C. Greve. 2013. 'Introduction: Public-private partnerships in turbulent times'. In C. Greve and G. Hodge (eds) Rethinking Public-Private Partnerships: Strategies for turbulent times. London: Routledge. doi.org/10.1016/b978-0-7020-4356-7.00001-x.

Hodge, G. A., C. Greve and A. E. Boardman (eds). 2010. International Handbook on Public-Private Partnerships. Cheltenham, UK: Edward Elgar.

Huang, H. 2008. Challenges and opportunities for infrastructure development in Taiwan. Economic Analysis Paper, June. Taipei: Taiwan Institute of Economic Research. Available from: english.tier.org.tw/eng_analysis/ EA200806_6.asp (accessed 17 July 2017). 
Huang, Y. L. 1995. 'Project and policy analysis of build-operate-transfer infrastructure development'. PhD dissertation. Department of Civil Engineering, University of California at Berkeley.

Invest Taiwan. 2015. 'Taipei: Invest Taiwan'. Available from: investintaiwan. nat.gov.tw/homePage?lang=eng (accessed 17 July 2017).

Marris, S. 2008. 'Infrastructure fund to help development'. The Australian, 13 May. Available from: www.theaustralian.com.au/archive/nationalaffairs/infrastructure-fund-to-help-development/news-story/5ae0351 7d92d2a3f14c95218c85b7ca2 (accessed 28 August 2017).

Ministry of Finance (MoF). 2013. Promotion of Private Participation. Taipei: MoF. Available from: ppp.mof.gov.tw/PPP.Website/English/ Default.aspx (accessed 17 July 2017).

Ministry of Finance (MoF). 2015. Private Participation in Infrastructure Projects: Investor's manual projects. Taipei: MoF. Available from: ppp. mof.gov.tw (accessed 17 July 2017).

Ministry of Justice (MoJ). 2015. Laws and Regulations Database of the Republic of China. Taipei: MoJ. Available from: law.moj.gov.tw/Eng/ (accessed 17 July 2017).

National Development Council (NDC). 2015. 'Taipei City: NDC'. Available from: www.ndc.gov.tw/en/ (accessed 17 July 2017).

Organisation for Economic Co-operation and Development (OECD). 2012. Recommendations of the Council on Principles for Public Governance of Public-Private Partnerships. Paris: OECD Publishing.

Pianin, E. 2016. 'Trump's $\$ 1$ trillion infrastructure plan raises a red flag for Dems'. The Fiscal Times, 21 November. Available from: www.the fiscaltimes.com/2016/11/21/Trump-s-1 Trillion-Infrastructure-PlanRaises-Red-Flag-Dems (accessed 17 July 2017).

Reeves, E. 2015. 'A review of the PPP experience in Ireland: Lessons for comparative policy analysis'. Journal of Comparative Policy Analysis: Research and Practice 17(5): 467-80. doi.org/10.1080/13876988.20 15.1023018 . 
Ross, T. W. and J. Yan. 2015. 'Comparing public-private partnerships and traditional public procurement: Efficiency vs. flexibility'. Journal of Comparative Policy Analysis: Research and Practice 17(5): 448-66. doi.org/10.1080/13876988.2015.1029333.

Wu, L. 2014. 'A study on the water infrastructure investment efficiency in the western rural areas of China: From the perspective of public service capacity'. Presentation to 2014 International Conference on Public Administration, University of Electronic Science and Technology of China, Chengdu, China, 24-26 October.

Wu, W. 1999. 'Reforming China's institutional environment for urban infrastructure provision'. Urban Studies 36(13): 2263-82. doi.org/ 10.1080/0042098992412.

Wu, W. 2008. 'Urban infrastructure financing and regional economic performance under China's fiscal decentralization'. Presentation to Symposium on Local Public Finance and Property Taxation in China, Lincoln Institute of Land Policy, Cambridge, MA, 12 May.

Wu, W. and L. Wang. 2011. 'Study on the current situation, problems and countermeasures of the water infrastructure in China'. [In Chinese]. Macroeconomic Management 11: 36-8.

Zhao, Z. and C. Cao. 2011. 'Funding China's urban infrastructure: Revenue structure and financing approaches'. Public Finance and Management 11(3): 284-305.

\section{Appendix 11.1 Sections of the Statute for Encouragement of Private Participation in Transportation Infrastructure Projects}

Article 28 states: A private entity encouraged under this Statute may be exempted from the business income tax for a maximum period of five (5) years from the year in which taxable income is derived after the commencement of operation of the transportation infrastructure project concerned.

Article 29 indicates: A private entity encouraged under this Statute may credit 5 per cent to 20 per cent of the amount of the following expenditures against the business income tax payable for the current year: 
V. Capital expenditures invested in building, operation equipment or technology.

VI. Capital expenditures invested in procurement of pollution control equipment or technology.

VII. Capital expenditures invested in research and development $(\mathrm{R} \& \mathrm{D})$, and personnel training.

VIII. Other investment expenditures as approved by the Executive Yuan.

Article 30 provides that: The machinery, equipment, special transporting vehicles, training apparatus and the required parts/components thereof which are imported by a private entity encouraged under this Statute for use in building the transportation infrastructure projects concerned shall be exempted from customs duties; provided that the purpose of use of such items is confirmed by Ministry of Transportation and Communications, and it is certified by Ministry of Economic Affairs that such items have not yet been manufactured and supplied domestically.

\section{Appendix 11.2 i-Taiwan 12 projects}

\section{Island-wide Transportation Network}

- MRT networks in northern, central and southern metropolitan areas.

- Northern metropolitan MRT network: Linking of Taipei MRT with Tucheng, Sanxia, Yingge, Wanhua, Zhonghe, Shulin, Ankeng, Xizhi and Danhai; Keelung-Taoyuan-Taipei rail links; regional light-rail transit network linking Shezi, Shilin and Beitou.

- Central metropolitan MRT network: Linking Taichung, Wuri, Changhua, Fengyuan, Wuqi, Dali, Wufeng, Caotun and Nantou.

- Southern metropolitan MRT network: Chiayi High-Speed Rail Station to the urban area; Tainan MRT; extension of Kaohsiung MRT to Gangshan, Luzhu and Pingtung and continued construction of latter-stage network.

- Elimination of railway level crossings and transformation of rail lines into rapid transit systems, in northern, central and southern metropolitan areas.

- Electrification and double-tracking of the eastern railway. 
- Purchase of passenger cars for the Neiwan Branch Line of the Taiwan Railway in Hsinchu, the Shalun Branch Line in Tainan and the East Coast Line.

- Integration of the freeway and highway systems.

\section{Kaohsiung Free Trade and Ecology Harbour}

- Construction of international container centre at Kaohsiung Harbour.

- Construction of a harbour eco-park and establishment of a marine technology and cultural centre.

- Transformation of the Qijin area into an international-class marine recreation area.

- Transformation of old harbour areas at Hamaxing, Gushan and Lingya.

- Expansion of warehousing and logistics facilities at Kaohsiung International Airport and improvement of peripheral transportation.

\section{Taichung Asia-Pacific Sea-Air Logistics Centre}

- Construction of a shipping network linking Taichung Harbour, Taichung Airport, the Central Taiwan Science Park and Changhua coast to provide an Asia-Pacific sea-air logistics centre.

- Expansion of the Central Taiwan International Airport and development of an air cargo terminal.

- Establishment of a warehousing, logistics and value-added processing zone.

\section{Taoyuan International Aviation City}

- Promotion of the enactment of the Special Act for the Taoyuan Aviation City, aimed at transforming Taoyuan International Airport into a 6,150-hectare Asia-Pacific international aviation city.

- Completion of the third terminal in 2018, followed by the fourth terminal and third runway.

- Renovation of Terminal 1.

- Construction of a comprehensive access network for the aviation city. 


\section{Intelligent Taiwan}

\section{Personnel development}

- Strengthening of education in language and information, elimination of the urban-rural gap and the digital divide and encouragement of lifetime learning investment, the implementation of tuition-free high and vocational schools and the improvement of teachers, facilities and curricula in technical and vocational schools. Implementation of the eight-year, NT $\$ 80$ billion (A $\$ 3.4$ billion) Advance Toward Elite Universities and Educational Excellence plans with the goal of bringing research results up to world standards.

\section{Cultural and creative industries}

- Promotion of the Cultural and Creative Industries Development Act, establishment of cultural, creative and digital industrial parks; allocation of NT\$10 billion (A \$421.8 million) from the National Development Fund for start-up investment in enterprises related to cultural and creative industries; earmarking of a budget to provide incentives for operators in the cultural, creative and digital content industries to engage in international marketing and participate in international exhibitions.

- Development of Taiwan as a 'World No. 1 Wireless Broadband Country'.

- Extension of Taipei's 'Wireless City' experience to all major metropolitan areas throughout the country, with the installation of citywide wireless internet connectivity, and the building of a 'wireless freeway' that allows remote areas to enjoy the same wireless services as the cities.

- Development of an intelligent transportation system and intelligent living environment.

- Development of intelligent transportation management; intelligent integrated land, sea and air transportation; intelligent logistics and customs clearances; integrated and intelligent ticketing; and intelligent medical care, safety, funds flows and e-trading. 


\section{Industrial innovation corridors}

- Taipei-Keelung-Yilan Industrial Innovation Corridor: In addition to the existing Neihu Technology Park and Nangang Software Park, construction of a new Beitou-Shilin Technology Park, Keelung Taipei Consolidated Technology Park, Taipei County Game Industry and Cultural Industrial Park and Yilan Science Park.

- Taoyuan-Hsinchu-Miaoli Industrial Innovation Corridor: Accelerated development of the Taoyuan Aviation Technology Park, Longtan base of the Hsinchu Science Park, fourth-stage expansion of the Zhunan base and Tonglo Defence Technology Park; establishment of 'international villages' to attract high-level professionals from overseas.

- Taichung-Changhua-Nantou Industrial Innovation Corridor: Establishment of a Changhua base of the Central Taiwan Science Park and a central Taiwan branch of the Industrial Technology Research Institute.

- Yunlin-Chiayi-Tainan Industrial Innovation Corridor: Development of agricultural biotechnology industries southwards from the central west coast.

- Kaohsiung-Pingtung-Penghu Industrial Innovation Corridor: Expansion of the Kaohsiung Software Park into an innovative technological R\&D park, with residents such as branches of major central government research institutions, including the Industrial Technology Research Institute and the Institute for Information Industry.

- Hualien-Taitung Industrial Innovation Corridor: Provision of assistance to Hualien County in the establishment of a Stone Art Innovation Park, assistance for the development of the deep-ocean industry on the east coast and help for Taitung County in the establishment of a deep-water industrial park.

\section{Urban and industrial park renewal}

- Northern Taiwan: Implementation of the Capital Centre Historical Preservation and Redevelopment Plan and revitalisation of the positioning function and the Keelung Railway Station and Harbour Shore Renewal Plan.

- Central Taiwan: Renewal of Zhongxing New Village as a cultural, creative and high-level R\&D park, and redevelopment of the former Shuinan Airport site. 
- Southern Taiwan: Harbour Shore Redevelopment Plan for the mouth of the Love River in Kaohsiung City.

- Renewal and development of former industrial zones in northern, central and southern Taiwan.

- Development of new high-speed rail stations (in Nangang, Miaoli, Changhua and Yunlin) and special station zones.

\section{Agricultural village revival}

- Promotion of the enactment of the Agricultural Village Revival Act 2010, providing care for 600,000 farm families in 4,000 rural communities; establishment of a retirement mechanism for farmers (with the government providing NT\$30 billion [A $\$ 1.3$ billion] in interest subsidies); implementation of the 'Small Landlord, Large Tenant' system; encouragement of professional farmers to expand and industrialise their operations; and large-scale release of unsuitable farmland under a graded area management and rational payback mechanism to enhance the efficiency of utilisation of national land.

\section{Seashore regeneration}

- Removal of sediment from fishing harbours throughout Taiwan on a regular basis, re-engineering of traditional fishing harbours into modern dual-purpose fishing and tourist harbours and relaxation of restrictions on coastal yachting activities.

- Promotion of international investment in the development of coastal scenic spots and the building of coastal living and travel areas; development of cruise-ship tourism and promotion of Kaohsiung, Keelung and Hualien harbours as ports of call on international cruise routes; and review of forest protection and release of those areas that present no national security or ecological concerns, to enliven the use of coastal land.

\section{Greening afforestation}

- Afforestation of 60,000 hectares of flatland within eight years and development of three 1,000-hectare flatland forest recreation areas in central and southern Taiwan. 


\section{Flood control and river rectification}

- Overall review of flood control plans, strengthening implementation and evaluation and increasing budgets where necessary.

- Implementation of the Special Act for Gaoping River Rectification 2010 and use of a special fund to control flooding and pollution of the river.

- Strengthened injection of groundwater to improve the land subsidence situation; implementation of a general forest fire prevention plan; delineation of areas of mudflow danger and environmental sensitivity; and establishment of a mudflow monitoring and early warning system.

- Allocation of a four-year budget of NT\$50 billion (A $\$ 2.1$ billion) for the rebuilding of aboriginal homelands and the promotion of land conservation.

\section{Sewer construction}

- Construction of sewer lines to raise the sewerage connection ratio by 3 per cent per year, and strengthened construction of small-scale sewerage systems in remote and mountain areas to ensure the quality of water sources. 
This text is taken from Value for Money: Budget and financial management reform in the People's Republic of China, Taiwan and Australia, edited by Andrew Podger, Tsai-tsu Su, John Wanna, Hon S. Chan and Meili Niu, published 2018 by ANU Press, The Australian National University, Canberra, Australia. 